\title{
PERAN PEMERINTAH TERHADAP LANJUT USIA PADA PANTI SOSIAL TRESNA WERDHA SINTA RANGKANG DI KOTA PALANGKA RAYA
}

\author{
Rahmaniar, Enriko Tedja Sukmana dan Sri Wulandari
}

\begin{abstract}
abstrack
Elderly was someone who was at the age of 60 years and older with conditions of reduced function of the health, social and economic. The condition was often the elderly had problems in terms of neglected or abandoned by families and communities. Overcoming the problems of the elderly in neglected or abandoned, the government has been providing social welfare institution of Tresna Werdha Sinta Rangkang for the elderly. Social welfare institution was a residence for the elderly who did not had a place to stay with the purpose of empowering the neglected elderly and abandoned. However, such observations can be in social welfare institution have a policy that only receives elderly healthy and independent. In fact, that should be more in need were elderly who were not in these circumstances in order to be empowered in this social institution.Then, with the issue of this study discusses the role of government to the elderly at social welfare institution of tresna Werdha Sinta rangkang in the city of Palangkaraya. The formulation of the problem, namely: (1) What is the role of government on the economy of the elderly in the city of Palangkaraya. (2) How is the role of government to the elderly in Social Welfare Institution Tresna Werdha Sinta rangkang.

This study, a field research using qualitative descriptive approach.The object of this study is the role of government in the city of Palangka Raya and the research subject is the section head elderly Provincial and head of the Social Welfare Institution of Tresna Werdha Sinta Rangkang in the city of Palangkaraya. Methods of data collection by observation, interview and documentation.

This results indicate that the function of government on the economy of the elderly in the city of Palangka Raya with the function of community empowerment through productive economic business assistance program. The assistance was in addition to venture capital for income elderly. Then the role of the government to social welfare institution Tresna Werdha Sinta Rangkang with service function society through meeting the needs of the elderly both in compliance with food and clothing and health care. It was the role of government to the elderly was maximal however, further enhanced by not limiting the client acceptance process
\end{abstract}

Keywords: Role of Government, Elderly, Social Welfare Institution.

\section{A. Pendahuluan}

Pada saat lanjut usia, banyak orang sering beranggapan mereka yang berada pada tahap ini sudah tidak produktif lagi. Saat kondisi ini, Islam menganjurkan menghadapi mereka yang berusia lanjut perlu seteliti dan setelaten mungkin yang diberikan kepada anakanak mereka. Allah memerintahkan perlakuan secara khusus untuk anak-anaknya agar kedua orang tua yang berada pada usia lanjut untuk memperlakukannya dengan penuh kasih sayang. ${ }^{1}$

\footnotetext{
${ }^{1}$ Hamdanah, Psikologi Perkembangan, Malang: Setara Press, 2009, h. 156.
} 
Sebagaimana acuan dalam memberikan perlakuan yang baik kepada orang tua terdapat dalam firman Allah Q.S Al-Israa' ayat 23 yang berbunyi :

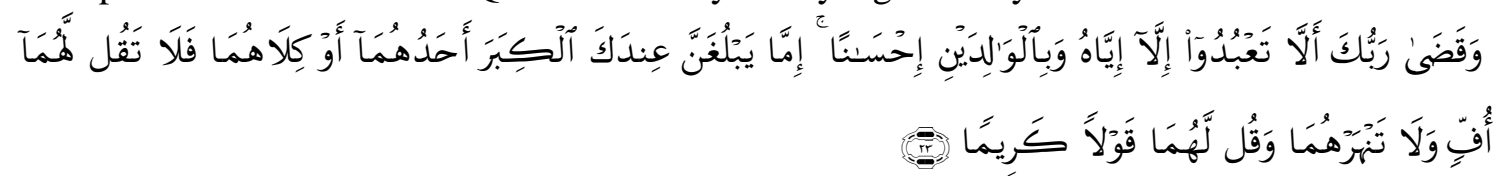

Artinya : Dan Tuhanmu telah memerintahkan agar kamu jangan menyembah selain Dia dan hendaklah berbuat baik kepada ibu-bapak. Jika salah seorang di antara keduanya atau kedua-duanya sampai berusia lanjut dalam pemeliharaanmu, maka sekalikali janganlah engkau mengatakan kepada keduanya perkataan "ah" dan janganlah engkau membentak keduanya, dan ucapkanlah kepada keduanya perkataan yang baik. ${ }^{2}$

Sebagaimana ayat di atas menyatakan bahwa Allah SWT. berfirman Allah telah memerintahkan dan memberi pesan janganlah kamu menyembah selain Dia dan selain itu hendaklah kamu berbuat dan bersikap baik dan hormat terhadap kedua ibu bapakmu. Jika kedua orang tuamu atau salah seorang di antara keduanya sampai berumur lanjut dalam pemeliharaanmu, maka janganlah sekali-kali kamu memperdengarkan kepada mereka atau kepada salah seorang di antara mereka kata-kata yang kasar dan tidak sopan bahkan kata "ah". Dan janganlah membentak-bentak mereka berdua atau salah seorang di antara mereka, namun hendaklah kamu mengucapkan kata-kata yang hormat, sopan, lemah lembut di hadapan mereka. ${ }^{3}$

Pada saat orang tua sudah mencapai pada tahap yang tidak memungkinkan lagi untuknya bekerja, maka peran serta anak dan keluarga sangatlah dibutuhkan. Seseorang yang sudah memasuki tahap ini disebut sebagai lanjut usia. Lanjut usia adalah seseorang yang telah mencapai usia 60 tahun ke atas. Lanjut usia merupakan fase menurunnya kemampuan akal dan fisik yang dimulai dengan adanya beberapa perubahan dalam hidup. ${ }^{4}$

Umumnya pada saat seseorang yang sudah lanjut usia banyak mengalami kemunduran dari segi fisik, psikologis, sosial, ekonomi dan kesehatan. Kebutuhan hidup orang lanjut usia yang sangat diperlukan antara lain kebutuhan akan makanan bergizi seimbang, pemeriksaan kesehatan secara rutin dan perumahan yang sehat dan kondisi rumah yang tentram dan aman. Hal ini kepedulian dan kebijakan pemerintah serta masyarakat terutama peranan keluarga dalam melindungi seorang lanjut usia sangat dibutuhkan untuk mengantisipasi dan menangani lanjut usia yang mengalami permasalahan tersebut. Pemerintah juga bertugas untuk mengarahkan, mengatur, dan mengendalikan kegiatan ekonomi melalui berbagai kebijakan, peraturan perundang-undangan dan tindakan langsung di lapangan termasuk dalam perekonomian lanjut usia. Mengenai perlindungan lanjut usia juga telah diberikan oleh Negara dengan dikeluarkannya Undang-Undang Nomor 13 Tahun 1998 Tentang kesejahteraan lanjut usia dan Peraturan Pemerintah Nomor 43 Tahun 2004 tentang pelaksanaan upaya peningkatan kesejahteraan sosial lanjut usia, yang pada umumnya mewajibkan pemerintah, masyarakat dan keluarga untuk bertanggung jawab atas terwujudnya upaya peningkatan kesejateraan sosial lanjut usia dengan memberikan hak kepada lanjut usia

\footnotetext{
${ }^{2}$ Departemen Agama RI, Al-Qur'an dan Terjemah, Surabaya: Karya Agung, 2006, h.387.

${ }^{3}$ Ibnu Katsir, Tafsir Ibnu Katsir Jilid 5, Terjemahan Salim Bahreisy dan Said bahreisy, Surabaya: PT. Bina Ilmu, 2002. h. 30.

${ }^{4}$ Kebutuhan Orang Lanjut Usia, Http://Www.Psychologymania. Com/2012/07/Kebutuhan-HidupOrang-Lanjut-Usia.Html. (Di akses Pada 08 Maret 2015)
} 
berupa pelayanan keagamaan dan mental spiritual, pelayanan pendidikan dan pelatihan, pelayanan untuk mendapatkan kemudahan dalam menggunakan fasilitas, sarana, dan prasarana umum, pemberian kemudahan dalam pelayanan hukum dan bantuan sosial. Ketentuan untuk memenuhi hak lanjut usia juga sudah diatur dalam pasal 42 Undang-Undang No 39 Tahun 1999 tentang hak asasi manusia yang menyatakan bahwa setiap warga negara yang berusia lanjut, cacat fisik dan atau cacat mental berhak memperoleh perawatan, pendidikan, pelatihan, dan bantuan khusus atas biaya Negara untuk menjamin kehidupan yang layak sesuai dengan martabat kemanusiaannya, meningkatkan rasa percaya diri dan kemampuan berpartisipasi dalam kehidupan bermasyarakat, maka dalam hal ini tentunya pemerintah jelas memiliki peran strategis untuk mengatasi masalah lansia. ${ }^{5}$

Berdasarkan hasil observasi yang dilakukan di kota Palangka Raya di sebuah lembaga Panti Sosial Tresna Werdha Sinta Rangkang yang berada di Jl. Tjilik Riwut Km 31, ditemukan bahwa peran pemerintah terhadap lanjut usia yang berada di Panti Sosial Tresna Werdha Sinta Rangkang sudah cukup baik, karena semua biaya hidup para lansia yang tinggal di panti sosial sudah ditanggung oleh pemerintah dengan syarat lansia tersebut dalam keadaan fisik sehat dan mandiri. ${ }^{6}$

Namun demikian, secara tidak langsung dapat dikatakan ada kebijakan yang dibuat oleh pemerintah bahwa tidak menerima lansia jika dalam keadaan cacat seperti lumpuh dengan alasan tidak tersedianya tenaga yang bertugas mengurus lansia dengan kondisi tersebut. Melihat kebijakan tersebut ada permasalahan yaitu tentu sangat membutuhkan penanganan dan pelayanan sebenarnya para lanjut usia dalam keadaan cacat dan ini sudah menjadi tugas penting bagi pemerintah dalam memberikan jaminan perlindungan serta perhatian dan juga sebagai tanggung jawab pemerintah dalam memberikan kesejahteraan sosial bagi lanjut usia.

Namun, upaya pemerintah dalam memberikan pelayanan kesejahteraan sosial lanjut usia yang tidak produktif di kota Palangka Raya masih kurang jika dilihat dari adanya syarat untuk masuk dalam panti sosial tresna werdha sinta rangkang hanya untuk lanjut usia dalam keadaan sehat dan mandiri yang dapat masuk dalam panti tersebut. Melihat kondisi ini peran pemerintah masih kurang maksimal. Sehingga, penulis berkesimpulan mengambil sebuah judul tentang "Peran Pemerintah Terhadap Lansia Di Panti Sosial Tresna Werdha Sinta Rangkang Kota Palangka Raya"

\section{B. Landasan Teori \\ a. Peran dan Fungsi Pemerintah 1. Definisi Peran Pemerintah}

Menurut kamus bahasa Indonesia peranan diambil dari kata peran yang berarti pemain, yang memiliki beberapa arti yakni; pemain (sandiwara); tukang lawak dan perangkat, tingkah laku yang diharapkan dimiliki oleh orang yang berkedudukan di masyarakat sedangkan kata peranan diartikan dalam dua makna yakni bagian yang dimainkan pemain; dan tindakan yang dilakukan oleh seseorang dalam suatu peristiwa. ${ }^{7}$

\footnotetext{
${ }^{5}$ Muhadditsir Rifa'i, Memaknai Kembali Birr Al-Walidain: Suplemen Swara Rahima Edisi 46,Http://www.rahima.or.id/index.php.article\&catid=Asuplemen\&id=1253A2014-11-04-04-1633\&format=pdf\&option.com.content\&Itemid. (Di akses pada 08 Maret 2015)

${ }^{6}$ Wawancara dengan “AN” pada tanggal 17 Maret 2016, di Kota Palangka Raya.

${ }^{7}$ Tim Penyusun Kamus Pusat Bahasa, Kamus Besar Bahasa Indonesia, Edisi Ke Tiga, Balai Pustaka, Jakarta: 2007, h. 854.
} 
Secara etimologi, kata pemerintah berasal dari kata "perintah" berarti sesuatu yang harus dilaksanakan, kemudian mendapat imbuhan sebagai berikut :

1) awalan "pe" menjadi kata "pemerintah" yang berarti badan atau organ yang melaksanakan pekerjaan mengurus suatu negara atau organ yang menjalankan pemerintahan.

2) akhiran "an" menjadi kata "pemerintahan" yang berarti perihal, cara, perbuatan atau urusan dari badan yang berkuasa dan memiliki legitimasi. ${ }^{8}$

Menurut Ermayana Suradinata sebagaimana dikutip oleh Zaidan Nawawi dalam bukunya berjudul manajemen Pemerintah mengatakan bahwa pemerintah adalah sebagai lembaga atau badan-badan publik yang mempunyai fungsi melakukan upaya untuk mencapai tujuan Negara. ${ }^{9}$

Sedangkan menurut Kamus Bahasa Indonesia, pemerintah adalah sistem menjalankan wewenang dan kekuasaan mengatur kehidupan sosial, ekonomi, dan politik suatu negara atau penguasa suatu Negara. ${ }^{10}$

Dapat disimpulkan, peran pemerintah adalah suatu perilaku yang diinginkan oleh masyarakat untuk menciptakan segala perhatian dalam urusan baik dalam keagamaan dan kepercayaan serta mengontrol ekonomi dan keamanan kehidupan sosial.

\section{Fungsi Pemerintah}

Pemerintah merupakan sesuatu yang berhubungan langsung dalam kehidupan bermasyarakat baik hubungan antara manusia dengan setiap kelompok masyarakat maupun keluarga. Berkenaan dengan hubungan masyarakat, pasti akan selalu menyangkut dengan unsur-unsur kebutuhan dasar manusia seperti makanan, pakaian dan sebagainya. Namun, apabila masyarakat tidak mampu dalam memenuhi segala kebutuhan dasarnya maka pemerintah harus dapat mengatasi permasalahan tersebut dengan menjalankan segala fungsinya sebagai pemerintah.

Menurut Ndraha dalam buku birokrasi pemerintahan, pemerintah memiliki dua fungsi, yaitu: pertama, fungsi primer (fungsi pelayanan) yaitu fungsi pemerintah sebagai jasa-jasa publik yang tidak dapat diprivatisasikan termasuk jasa hankam. Sedangkan fungsi pemerintah yang kedua fungsi sekunder (fungsi pembeerdayaan) yaitu sebagai provider kebutuhan dan tuntutan yang diperintahkan akan barang dan jasa yang mereka tidak mampu penuhi sendiri karena masih lemah dan tak berdaya termasuk penyediaan dan pembangunan sarana dan prasarana. ${ }^{11}$

Kemudian Rewansyah mengemukakan ada lima fungsi utama (main function) eksekutif (pemerintah) yaitu : ${ }^{12}$

a. Fungsi pengaturan atau Regulasi

Fungsi pengaturan atau Regulasi adalah fungsi yang tidak dapat didelegasikan, dipindahkan ataupun diprivatisasikan kepada organisasi atau lembaga di luar pemerintahan. Sesuai UUD 1945 pasal 1 ayat (3) di tetapkan di Negara Indonesia

\footnotetext{
${ }^{8}$ Abidarin Rosidi dan Anggraeni Fajriani, Reinventing Government:Demokrasi Dan Reformasi Pelayanan Publik, Yogyakarta: C.V Andi Offset, h. 5.

${ }^{9}$ Zaidan Nawawi, Manajemen Pemerintahan, Jakarta: Rajawali Pers, 2013, h. 19.

${ }^{10}$ Risa Agustin, Kamus Lengkap Bahasa Indonesia, Surabaya: Serba Jaya, t.t, h.488

${ }^{11}$ Delly Mustafa, Birokrasi Pemerintahan, Bandung: Alfabeta, 2014, h. 102

${ }^{12}$ Ibid., 103
} 
adalah Negara hukum, maka segala aspek kehidupan dalam bidang kemasyarakatan, kebangsaan dan kenegaraan termasuk pemerintah harus senantiasa berdasarkan hukum atau yang di atur dalam peraturan perundang-undangan. Dengan kata lain, segala sikap, perilaku dan perbuatan atau tindakan penyelengaraan Negara atau aparatur Negara harus mempunyai pijakan atau landasan hukum.

b. Fungsi pelayanan Kepada Masyarakat

Konsep pelayanan mengandung bermacam-macam arti, yang meliputi macam kegiatan dan dipakai untuk berbagai bidang studi. Layanan sebagai konsep pelayanan mengandung dua arti yaitu sebagai jasa (komoditi dalam arti luas) dan sebagai seni (cara). Sebagai komoditi dalam arti luas yaitu yang diperjualbelikan (layanan publik) maupun yang tidak diperjualbelikan (layanan civil dan layanan no price). Sedangkan pelayanan seni terbentuk sebagai upaya pejabat atau pegawai pemerintahan untuk mengefektifkan aktifitas pelayanannya sesuai dengan kondisi orang, makhluk atau lingkungan yang dilayani dalam kondisi apapun, pemerintah juga harus memiliki etika dan benar-benar (code of conduct) berkualitas.

c. Fungsi Pemberdayaan Masyarakat

Pemberdayaan masyarakat adalah fungsi yang berhubungan dengan kondisi ekonomi, politik dan sosial warga masyarakat. Misalnya, saat kondisi ekonomi masyarakat lemah, maka pemerintah harus menyelenggarakan pemberdayaan masyarakat melalui program pembagunan. ${ }^{13}$

Menurut Taliziduhu Ndraha dalam bukunya berjudul Kybernologi: sebuah Rekonstrusi Ilmu pemerintahan bahwa jenis pemberdayaan ada lima yaitu pemberdayaan struktural, pemberdayaan politikal, pemberdayaan ekonomikal, pemberdayaan sosiokultural dan pemberdayaan Filosofik-Etik. ${ }^{14}$

d. Fungsi pengelolaan Aset/kekayaan Negara

Aset atau kekayaan Negara merupakan segala sesuatu yang bernilai ekonomi baik berupa fisik dan non fisik maupun berupa uang, surat-surat berharga dan kekayaan alam yang terdapat di bumi Nusantara. Aset atau kekayaan Negara tak lain dari sumber daya yang terdapat di bumi Indonesia yang merupakan milik bangsa Indonesia. Sumber daya ini terdiri dari Sumber Daya Alam seperti ruang, waktu dan bumi beserta isinya, Sumber daya manusia dan sumberdaya buatan seperti ilmu, seni, teknologi, jalan, jembatan, gedung dan sebagainya.

e. Fungsi keamanan, ketertiban, pengamanan dan perlindungan (Polisional)

Fungsi pemerintah di bidang pertahanan, keamanan, ketertiban umum, pengamanan dan perlindungan sudah termasuk dengan fungsi pemerintahan di bidang perumusan kebijakan (pengaturan), pelayanan, pemberdayaan dan fungsi pengelolaan aset atau kekayaan negara. Misalnya melaksanakan fungsi pelayanan pengamanan dan perlindungan warga masyarakat dari berbagai gangguan keamanan. Fungsi pemerintah untuk menjaga keamanan, ketertiban,pengamanan dan kelestarian SDA dalam teritorial tanah air agar tidak terjadi pencurian kekayaan laut (ikan) serta mengelola aset atau kekayaan Negara untuk kemakmuran bangsa. ${ }^{15}$

\footnotetext{
${ }^{13}$ Ibid., h. 105

${ }^{14}$ Taliziduhu Ndraha, Kybernologi: Sebuah Rekonstrusi Ilmu Pemerintahan, Jakarta: PT. Rineka Cipta, 2005, h. 66.

${ }^{15}$ Delly Mustafa, Birokrasi Pemerintahan..., h. 109-110.
} 


\section{b. Konsep Lanjut Usia}

\section{Definisi Lanjut Usia}

Lanjut usia adalah bagian dari tumbuh kembang. Manusia tidak secara tiba-tiba menjadi tua, tetapi berkembang dari bayi, anak-anak, dewasa dan akhirnya menjadi tua. Semua orang akan mengalami proses menjadi tua dan masa tua merupakan masa hidup manusia yang terakhir dan di masa itu sesorang mengalami kemunduran fisik, mental dan sosial secara bertahap. ${ }^{16}$

Adapun definisi lanjut usia menurut beberapa pendapat yaitu :

a. Menurut Undang-undang No 13 tahun 1998 tentang kesejahteraan lanjut usia pada bab I pasal 1 ayat 2, yang dimaksud lanjut usia adalah seseorang yang mencapai usia 60 tahun ke atas.

b. Dra. Ny. Jos madani Nugroho mengemukakan bahwa lansia merupakan kelanjutan dari orang dewasa. ${ }^{17}$

c. Menurut Undang-Undang No 23 Tahun 1992 tentang kesehatan bahwa lanjut usia adalah seseorang yang karena usianya mengalami perubahan biologis, fisis, kejiwaan dan sosial. ${ }^{18}$

Berdasarkan dari beberapa pendapat para ahli, penulis menyimpulkan lanjut usia adalah seseorang berada pada beberapa perubahan dalam hidup yang berusia umur 60 tahun keatas.

\section{Batasan Umur Lanjut Usia}

Menurut badan kesehatan dunia (WHO) penggolongan lansia dikelompokkan menjadi empat yaitu : ${ }^{19}$

a. Usia pertengahan (middle age) 45-59 tahun

b. Lanjut usia (elderly) 60-74 tahun

c. Lanjut usia tua (old) 75-90 tahun

d. Usia sangat tua (very old) di atas 90 tahun

\section{Program Pemerintah untuk Lanjut usia Pada Sistem Panti Dan Non Panti}

a. Program pemerintah pada sistem Non Panti

1. Program asistensi sosial lanjut usia terlantar (ASLUT)

Program asistensi sosial lanjut usia terlantar (ASLUT) bertujuan untuk membantu pemenuhan sebagian kebutuhan dasar hidup lanjut usia sehingga dapat mempertahankan taraf kesejahteraan sosialnya. Untuk mencapai tujuan ini, program dilakukan dengan cara pemberian uang tunai kepada lanjut usia (yang memenuhi kriteria) per orang per bulan selama satu tahun melalui lembaga penyalur yang ditunjuk pemerintah. guna memastikan program berjalan sesuai

\footnotetext{
${ }^{16}$ Lilik Ma'rifatul Azizah, Keperawatan Lanjut Usia,Yogyakarta:Graha Ilmu, 2011,h. 1.

${ }^{17}$ Ibid., 2008, h. 350

${ }^{18}$ Tim Penyusun, Penjelasan Peraturan Perundang-Undangan, Jakarta: PT. Ichtiar Baru van Hoeve, 2010, h. 3 .

${ }^{19}$ Vina Dwi Wahyunita \& Fitrah, Memahami Kesehatan Pada Lansia, Jakarta: CV. Trans info media,
} 
dengan tujuan, proses pemanfaatan dana oleh lanjut usia dikendalikan oleh petugas pendamping yang ditunjuk melaksanakan fungsi pendampingan. ${ }^{20}$

2. Program Bantuan Usaha Ekonomi Produktif (UEP) Lanjut Usia

Program kegiatan usaha ekonomi produktif lanjut usia merupakan program pengentasan kemiskinan lanjut usia yang ditujukan bagi lanjut usia miskin namun tetap potensial dan telah memiliki embrio atau rintisan usaha dalam skala relatif kecil untuk menunjang kehidupan sosial ekonominya sehari-hari. Tujuan program UEP lanjut usia adalah untuk memberikan kesempatan kepada lanjut usia sehat, aktif, dan produktif agar tetap dapat menjalankan kegiatan usahanya yang dapat menjamin kelangsungan pendapatannya (income) nya guna memenuhi kebutuhannya sehari-hari. Bantuan bersifat langsung kepada lanjut usia, namun sasarannya benar-benar dipilih dari lanjut usia yang masih sehat, aktif, dan produktif.

3. Program Pendampingan dan Perawatan Sosial Lanjut Usia Di Rumah (Home Care)

Pendampingan dan perawatan sosial lanjut usia di rumah atau home care lanjut usia adalah bentuk pelayanan bagi lanjut usia yang berada di rumah atau di tengah-tengah keluarga dengan didampingi oleh seorang pendamping dalam pemenuhan kebutuhannya. Pendamping mempunyai peran pembantu serta melayani lanjut usia agar dapat melaksanakan fungsi sosialnya secara layak dan manusiawi. Pendampingan dan perawatan sosial lanjut usia di rumah disesuaikan dengan kebutuhan lanjut usia yang memiliki kriteria tersendiri. Home care lanjut usia memiliki beberapa fungsi antara lain pencegahan, promosi, rehabilitasi dan perlindungan serta pemeliharaan. ${ }^{21}$

b. Program Pemerintah Sistem Panti

1. Program Nursing Care

Perawatan Khusus (Nursing Care) lanjut usia merupakan pelayanan pendampingan dan perawatan lanjut usia di panti atau Lembaga yang dilaksanakan melalui kegiatan sehari-hari oleh tenaga profesional (pekerja sosial/ perawat/ dokter/ psikolog), dengan memiliki beberapa fungsi antara lain rehabilitasi dan perlindungan serta perawatan. ${ }^{22}$

2. Program kegiatan Pelayanan

Kegiatan pelayanan yang ditujukan untuk lanjut usia sebagai berikut $:^{23}$

- Pelayanan fisik (pengasramaan, permakanan, pakaian)

- Pelayanan keagamaan (bimbingan rohani, tuntunan beribadah)

- Pelayanan sosial (bimbingan individu/kelompok)

- Pelayanan keterampilan (kegiatan penyaluran hobi, dan pengisian waktu luang)

- Pelayanan psikologis (konsultasi, terapi kelompok)

- Pelayanan kesehatan (pemeriksaan kesehatan rutin, pemberian obat-obat ringan)

\footnotetext{
${ }^{20}$ Dokumen Dinas Sosial Provinsi Kalimantan Tengah

${ }^{21}$ Dokumen Dinas Sosial Provinsi Kalimantan Tengah

${ }^{22}$ Dokumen Dinas Sosial Provinsi

${ }^{23}$ Dokumen Panti Sosial Tresna Werdha Sinta Rangkang Di Kota Palangka Raya
} 
- Pelayanan pendampingan (mendampingi kegiatan sehari-hari, mendampingi kegiatan di luar panti)

- Rekreasi (dharmawisata, mendengarkan musik)

- Pelayanan pemakaman( pengurus jenazah)

\section{Fungsi Pemerintah Terhadap Perekonomian Lanjut Usia Di Kota Palangka Raya}

Upaya yang dilakukan pemerintah untuk mensejahterakan lanjut usia telah dilaksanakan, sesuai dengan fungsi pemerintah yaitu fungsi sebagai pemberdayaan masyarakat. Sebagaimana yang telah dilakukan melalui program bantuan usaha ekonomi produktif dengan tujuan agar lanjut usia dapat lebih mandiri dalam memenuhi kebutuhannya sehari-hari.

Program usaha ekonomi produktif adalah bantuan kegiatan usaha ekonomi yang ditujukan untuk lanjut usia sehat, aktif dan produktif. Tujuan program usaha ekonomi produktif lanjut usia adalah untuk memberikan kesempatan kepada lanjut usia sehat, aktif dan produktif agar tetap dapat menjalankan kegiatan usahanya yang dapat menjamin kelangsungan pendapatannya (income) nya guna memenuhi kebutuhannya sehari-hari. Bantuan bersifat langsung kepada lanjut usia, namun sasarannya benar-benar dipilih dari lanjut usia yang masih sehat, aktif, dan produktif. ${ }^{24}$

Bentuk bantuan berupa uang tunai di salurkan melalui dana dekonsentrasi yang diberikan kepada lanjut usia setelah melalui proses seleksi yang dilakukan dinas sosial Kabupaten/Kota dan dinas sosial provinsi yang mekanisme dan kriterianya ditetapkan dalam buku pedoman bantuan usaha ekonomi produktif. ${ }^{25}$

Berdasarkan uraian di atas penulis menyimpulkan bahwa upaya yang dilakukan pemerintah dalam membantu ekonomi lanjut usia yaitu melalui program bantuan usaha ekonomi produktif atau UEP yang merupakan bantuan berupa uang tunai untuk modal tambahan yang diberikan kepada lanjut usia yang sebelumnya sudah mempunyai usaha kecilkecilan. Dalam bentuk pemberian program ini yang mana langkah yang dilakukan dengan diberikan bimbingan bagaimana cara mengelola usaha tersebut. Dalam hal ini dapat dikatakan upaya pemerintah untuk mensejahterakan ekonomi lanjut usia melalui program bantuan usaha ekonomi produktif sangat efektif, hal tersebut dapat dikatakan cukup berhasil dalam memenuhi kebutuhan lanjut usia yang masih produktif namun tidak mempunyai modal dalam meningkatkan usahanya. Dengan adanya program bantuan usaha ekonomi produktif dapat terwujudnya kemandirian dan kesejahteraan para lanjut usia sehingga mereka tidak merasa terpuruk dengan keadaan mereka di masa tua. Hal ini terbukti dengan kondisi lanjut usia yang membaik lanjut usia yang produktif dapat mandiri dalam memenuhi kebutuhannya sehari-hari melalui usaha kecil-kecilan.

\section{Peran Pemerintah Terhadap Panti Sosial Tresna Werdha Sinta Rangkang Di Kota Palangka Raya}

\footnotetext{
${ }^{24}$ Dokumen Dinas sosial Provinsi kalimantan Tengah

${ }^{25}$ Dokumen Dinas sosial Provinsi kalimantan Tengah
} 
Menghadapi permasalahan penduduk lanjut usia, pemerintah mempunyai programprogram untuk menangani permasalahan yang di hadapi oleh lanjut usia. Seperti halnya program untuk sistem pelayanan di luar panti sosial. Selain program tersebut pemerintah mengatasi permasalahan lanjut usia melalui pelayanan sistem panti sosial untuk para lanjut usia terlantar maupun ditelantarkan.

Pelayanan untuk lanjut usia yang berada pada panti sosial tresna werdha sinta rangkang dengan melalui program reguler adalah program pokok dinas sosial provinsi kalimantan tengah, di mana program ini menyelenggarakan pelayanan kesejahteraan sosial bagi lanjut usia yang berasal dari keluarga yang tidak mampu tanpa di pungut biaya dan para lanjut usia di tampung dalam asrama. ${ }^{26}$

Berikut merupakan kegiatan pelayanan yang ditujukan untuk lanjut usia :

a. Pelayanan fisik (pengasramaan, permakanan, pakaian)

b. Pelayanan keagamaan (bimbingan rohani, tuntunan beribadah)

c. Pelayanan sosial (bimbingan individu/kelompok)

d. Pelayanan keterampilan (kegiatan penyaluran hobi, dan pengisian waktu luang)

e. Pelayanan psikologis (konsultasi, terapi kelompok)

f. Pelayanan kesehatan (pemeriksaan kesehatan rutin, pemberian obat-obat ringan)

g. Pelayanan pendampingan (mendampingi kegiatan sehari-hari, mendampingi kegiatan di luar panti)

h. Rekreasi (dharmawisata, mendengarkan musik)

i. Pelayanan pemakaman( pengurus jenazah). ${ }^{27}$

Di samping program pelayanan di atas dilaksanakan yang tidak kalah penting adalah program Nursing Care yang merupakan bagian dari pelayanan kesehatan. Perawatan Khusus (Nursing care) lanjut usia merupakan pelayanan pendampingan dan perawatan lanjut usia di panti atau lembaga yang dilaksanakan melalui kegiatan sehari-hari oleh tenaga profesional ( pekerja/ sosial /perawat / dokter /psikolog), dengan memiliki beberapa fungsi antara lain rehabilitas dan perlindungan serta perawatan. ${ }^{28}$

Program pelayanan yang sudah disebutkan di atas, disusun berdasarkan kebutuhan para lanjut usia dan kemudian dilaksanakan dalam berbagai kegiatan dan bimbingan pelayanan yang sesuai pada undang-undang No. 13 Tahun 1998 tentang kesejahteraan lanjut usia. $^{29}$

Berdasarkan uraian di atas peran pemerintah terhadap lanjut usia melalui sistem pelayanan panti sosial tresna werdha sinta rangkang cukup baik. Hal tersebut terbukti dengan memberikan program pelayanan kepada lanjut usia yang berada dalam panti sosial tresna werdha sinta rangkang sudah sesuai dengan undang-undang No. 13 Tahun 1998 tentang kesejahteraan lanjut usia.

Menjalankan program pelayanan yang dilaksanakan oleh pihak panti sosial tresna werdha sinta rangkang yang diberikan kepada lanjut usia dijalankan dengan baik. Program pelayanan yang diberikan sesuai dengan kebutuhan para lanjut usia seperti halnya memberi makanan harian kepada para lanjut usia 3 kali dalam 1 hari serta bimbingan kegiatan lainnya yang sudah terjadwal. Dengan adanya program pelayanan dalam panti sosial tresna werdha Sinta rangkang tersebut dapat membantu lanjut usia yang terlantar maupun ditelantarkan

\footnotetext{
${ }^{26}$ Dokumen Panti Sosial Tresna Werdha Sinta Rangkang Di Kota Palangka Raya

${ }^{27}$ Dokumen Panti Sosial Tresna Werdha Sinta Rangkang Di Kota Palangka Raya

${ }^{28}$ Dokumen Panti Sosial Tresna Werdha Sinta Rangkang Di Kota Palangka Raya

${ }^{29}$ Tim Penyusun, Penjelasan Peraturan Perundang-Undangan..., h. 620.
} 
dapat memenuhi segala kebutuhannya. Sehingga, dengan terpenuhinya kebutuhan maka lanjut usia dapat mencapai kesejahteraan sosial meskipun tidak berada dalam lingkungan keluarga.

\section{E. Penutup}

Berdasarkan hasil penelitian bahwa fungsi pemerintah terhadap perekonomian lanjut usia yaitu dengan fungsi pemerintah sebagai pemberdayaan masyarakat. Hal demikian dilakukan melalui program bantuan usaha ekonomi produktif yang merupakan program pengentasan kemiskinan bagi lanjut usia yang produktif dan mempunyai rintisan usaha kecil untuk menunjang kehidupan ekonomi sehari-hari. Untuk peran pemerintah terhadap lanjut usia dalam panti sosial tresna werdha sinta rangkang cukup maksimal, hal ini peran yang dilakukan pemerintah untuk mensejahterakan lanjut usia dengan membuat program maupun pelayanan dengan tujuan untuk memberdayakan lanjut usia agar dapat lebih mandiri saat di masa tua. Peran pemerintah untuk lanjut usia di panti sosial tresna werdha sinta rangkang kota Palangka Raya sesuai dengan fungsi sebagai pemerintah yaitu melaksanakan fungsi pelayanan masyarakat melalui pemberian program bimbingan kepada lanjut usia yang terdiri dari berbagai bimbingan dan kegiatan bersifat pemberian jasa yang berupa pembinaan, pelayanan kesehatan, penyantunan dan pemberian makan sandang dan pangan.

\section{F. Daftar Rujukan}

Abidarin Rosidi dan Anggraeni Fajriani, Reinventing Government:Demokrasi Dan Reformasi Pelayanan Publik, Yogyakarta: C.V Andi Offset.

Delly Mustafa, Birokrasi Pemerintahan, Bandung: Alfabeta, 2014,

Departemen Agama RI, Al-Qur'an dan Terjemah, Surabaya: Karya Agung, 2006.

Hamdanah, Psikologi Perkembangan, Malang: Setara Press, 2009.

Ibnu Katsir, Tafsir Ibnu Katsir Jilid 5, Terjemahan Salim Bahreisy dan Said bahreisy, Surabaya: PT. Bina Ilmu, 2002.

Lilik Ma'rifatul Azizah, Keperawatan Lanjut Usia,Yogyakarta:Graha Ilmu, 2011

Risa Agustin, Kamus Lengkap Bahasa Indonesia, Surabaya: Serba Jaya, t.t.

Taliziduhu Ndraha, Kybernologi: Sebuah Rekonstrusi Ilmu Pemerintahan, Jakarta: PT. Rineka Cipta, 2005.

Tim Penyusun Kamus Pusat Bahasa, Kamus Besar Bahasa Indonesia, Edisi Ke Tiga,

Balai Pustaka, Jakarta: 2007.

Vina Dwi Wahyunita \& Fitrah, Memahami Kesehatan Pada Lansia, Jakarta: CV. Trans info media, 2010.

Zaidan Nawawi, Manajemen Pemerintahan, Jakarta: Rajawali Pers, 2013.

Kebutuhan Orang Lanjut Usia, Http://Www.Psychologymania. Com/2012/07/KebutuhanHidup-Orang-Lanjut-Usia.Html. (Di akses Pada 08 Maret 2015)

Muhadditsir Rifa'i, Memaknai Kembali Birr Al-Walidain: Suplemen Swara Rahima Edisi 46, Http://www.rahima.or.id/index.php.article\&catid=Asuplemen\&id=1253A2014-11-04-04-1633\&format=pdf\&option.com.content\&Itemid. (Di akses pada 08 Maret 2015) 